\title{
Assessment of land use change and its effect on soil carbon stock using multitemporal satellite data in semiarid region of Rajasthan, India
}

\author{
${\text { Garima Sharma }{ }^{1 *}, \text { L. K. Sharma }{ }^{1} \text { and K. C. Sharma }}^{2}$
}

\begin{abstract}
Background: Land use change plays a vital role in global carbon dynamics. Understanding land use change impact on soil carbon stock is crucial for implementing land use management to increase carbon stock and reducing carbon emission. Therefore, the objective of our study was to determine land use change and to assess its effect on soil carbon stock in semi-arid part of Rajasthan, India. Landsat temporal satellite data of Pushkar valley region of Rajasthan acquired on 1993, 2003, and 2014 were analyzed to assess land use change. Internal trading of land use was depicted through matrices. Soil organic carbon (SOC) stock was calculated for soil to a depth of $30 \mathrm{~cm}$ in each land use type in 2014 using field data collection. The SOC stock for previous years was estimated using stock change factor. The effect of land use change on SOC stock was determined by calculating change in SOC stock (t/ha) by deducting the base-year SOC stock from the final year stock of a particular land use conversion.

Results: The total area under agricultural lands was increased by $32.14 \%$ while that under forest was decreased by 23.14\% during the time period of 1993-2014. Overall land use change shows that in both the periods (1993-2003 and 2003-2014), 7\% of forest area was converted to agricultural land and about 15\% changes occurred among agricultural land. In 1993-2003, changes among agricultural land led to maximum loss of soil carbon, i.e., 4.88 Mt C and during 2003-2014, conversion of forest to agricultural land led to loss in 3.16 Mt C.

Conclusion: There was a continuous decrease in forest area and increase in cultivated area in each time period. Land use change led to alteration in carbon equity in soil due to change or loss in vegetation. Overall, we can conclude that the internal trading of land use area during the 10-year period (1993-2003) led to net loss of SOC stock by 8.29 Mt C. Similarly, land use change during 11-year period (2003-2014) caused net loss of SOC by $2.76 \mathrm{Mt} \mathrm{C}$. Efforts should be made to implement proper land use management practices to enhance the SOC content.
\end{abstract}

Keywords: Multitemporal satellite data, Land use change dynamics, Internal trading of land use, SOC stock, Stock change factor, Change in SOC pool, Land use management

\footnotetext{
*Correspondence: garimaenviro@gmail.com

'Department of Environmental Science, Central University of Rajasthan, NH-8,

Bandarsindri, Rajasthan 305817, India

Full list of author information is available at the end of the article
} 


\section{Background}

Land use can be define as "The set of anthropogenic activities and arrangements (e.g., cultivation, grazing, timber extraction) in a piece of land for economic and social welfare" (IPCC 2000). Land use change has been recognized as a global concern as it is one of the main reasons for environmental change. Land use patterns, controlled by various social activities, lead to change in land use that has adverse effect on global climate and biosphere through emission of greenhouse gases (GHGs) and alteration in biodiversity (Schreier 1994; Bajracharya 2004). Land use change from forest to agricultural land (deforestation) is supposed to be one of the anthropogenic activities culprit for increased atmospheric level of carbon dioxide (Shrestha et al. 2004; Houghton and Hackler 1999; Lal 2004a). Thus, globally, the rate of emission of carbon from change in land use has been gradually rising over the last 150 years (18502000), which reached to about $2 \mathrm{Pg} \mathrm{C}$ per year (Houghton and Hackler, 2002). Also, the net emissions of carbon dioxide in the last 150 years (1850-2000) due to land use change is about $156 \mathrm{Pg} \mathrm{C}$ (Houghton 2003). The $\mathrm{CO}_{2}$ emission from land use change was estimated to be $1.7 \mathrm{Pg} \mathrm{C}$ year $^{-1}$ in 1980-1989, $1.6 \mathrm{Pg} \mathrm{C}$ year $^{-1}$ in 1989-1998 (IPCC 2000), and 1.1 Pg C year ${ }^{-1}$ in 2000-2009 (Friedlingstein et al. 2010).

Land cover and land use change has a very prominent effect on soil carbon stock and its spread in ecosystem, and therefore plays a vital role in relation to global carbon dynamics. In particular, land cover and land use change result in loss in natural vegetation and alteration in equity between input and output of carbon from soil which leads to decrease in soil carbon stock (Ostle et al. 2009). Soil is the major carbon reservoir and has maximum carbon sequestration potential (Batjes 1996; Lal 2004; Lal 2005). The amount of carbon in soil (1500 Pg of carbon) is about two times more than present in the atmosphere $(750 \mathrm{Pg}$ of carbon) and thrice the amount stored in vegetation (650 Pg of carbon) (Powlson et al. 2011; Eswaran et al. 1993; Batjes and Sombroek 1997). Soil organic carbon is vital for increasing soil quality and its productivity and thus enhancing food production (Eswaran et al. 1993). Also increasing soil carbon storage is an effective method to mitigate increased level of carbon dioxide in atmosphere.

Many factors such as change in land use, land use management, climate change, etc. are responsible to control soil carbon stock (Xia et al. 2010). Land use change is a critical factor affecting soil carbon stock (Xia et al. 2011; Leifeld 2013). Land use change such as conversion from forest land to agricultural land leads to loss in soil carbon (Noordwijk et al. 1997; Lal 2001; Lal 2003; Lal 2004). Houghton (2003) observed that $156 \mathrm{Pg}$ of soil carbon is released into the atmosphere due to land use changes globally since 1850 . There is loss in soil organic carbon (SOC) by $20-50 \%$ when forest land is converted into cultivated land (Sombroek et al. 1993; Davidson and Ackerman 1993; Post and Kwon 2000; Amundson 2001; Murty et al. 2002; Don et al. 2011). Guo and Gifford (2002) reviewed previous literature and concluded that soil carbon stocks reduce when land is converted from grassland to cropland (-59\%), forest land to cropland (-42\%), forest to plantation (-13\%), and grassland to plantation $(-10 \%)$, whereas soil carbon stocks increase after land use changes from cropland to forest (+ $53 \%)$, cropland to grassland (+19\%), cropland to plantation $(+18 \%)$, and forest to grassland (+ $8 \%)$. Intensive cultivation change the natural ecosystems and disturbed the soil environment, leading to a significant loss of soil carbon (Detwiler 1986; Lou et al. 2010). Reduction in soil carbon stock also leads to poor soil quality and low plant productivity. Assessment of impact of land use change on soil carbon stock using multitemporal satellite data is studied by various researchers. Xia et al. (2010) revealed that land use changes had caused decrease in soil carbon by $30.7 \mathrm{Tg}$. Similarly, Dhakal et al. (2010) concluded that conversion of forest to cropland and other land uses has caused decrease in SOC, whereas vice versa has increased the SOC stock.

Detection of land use change is necessary to know its potential effect on soil carbon stock at regional level. Interpretation of satellite images obtained at different time and of the similar area has been the most used method to determine the temporal change in land use (Mulders 2001), and this method detect changes in land use with better accuracy, take short time, and also it is inexpensive (Kachhwala 1985). Mapping land use classification and detection of land use dynamics using satellite data has been executed since 1972. The most recent Landsat 8 was launched in 2013. The complete archive of Landsat is now freely accessible to the researcher and scientist for determining and examining manmade changes (Chander et al. 2009; Bastawesy 2014). Several international researchers (Dimyati et al. 1996; Lambin and Ehrlich 1997; Rembold et al. 2000; Li and Yeh, 2004; Yuan et al. 2005; Dewan and Yamaguchi, 2009; Gammal et al. 2010) and national researchers (Ram and Kolarkar 1993; Sharma et al. 2012; Pooja et al. 2012; Amin and Singh, 2012; Mehta et al. 2012; Singh et al. 2014) made exhaustive research efforts for detection of land use/land cover change using remote sensing data.

Understanding land-use change impact on soil carbon stock is crucial for implementing land use management to increase carbon stock and reducing carbon emission. Study on land use change analysis and its relationship to soil carbon stock in Pushkar valley region is not yet done. Pushkar valley of Rajasthan comes under semiarid region. Semi-arid region is severely degraded ecosystems around the world and has the great capacity for increasing soil carbon content. Improvements in land use management can increase the sequestration of carbon in the soil. Therefore, the objective of our study 


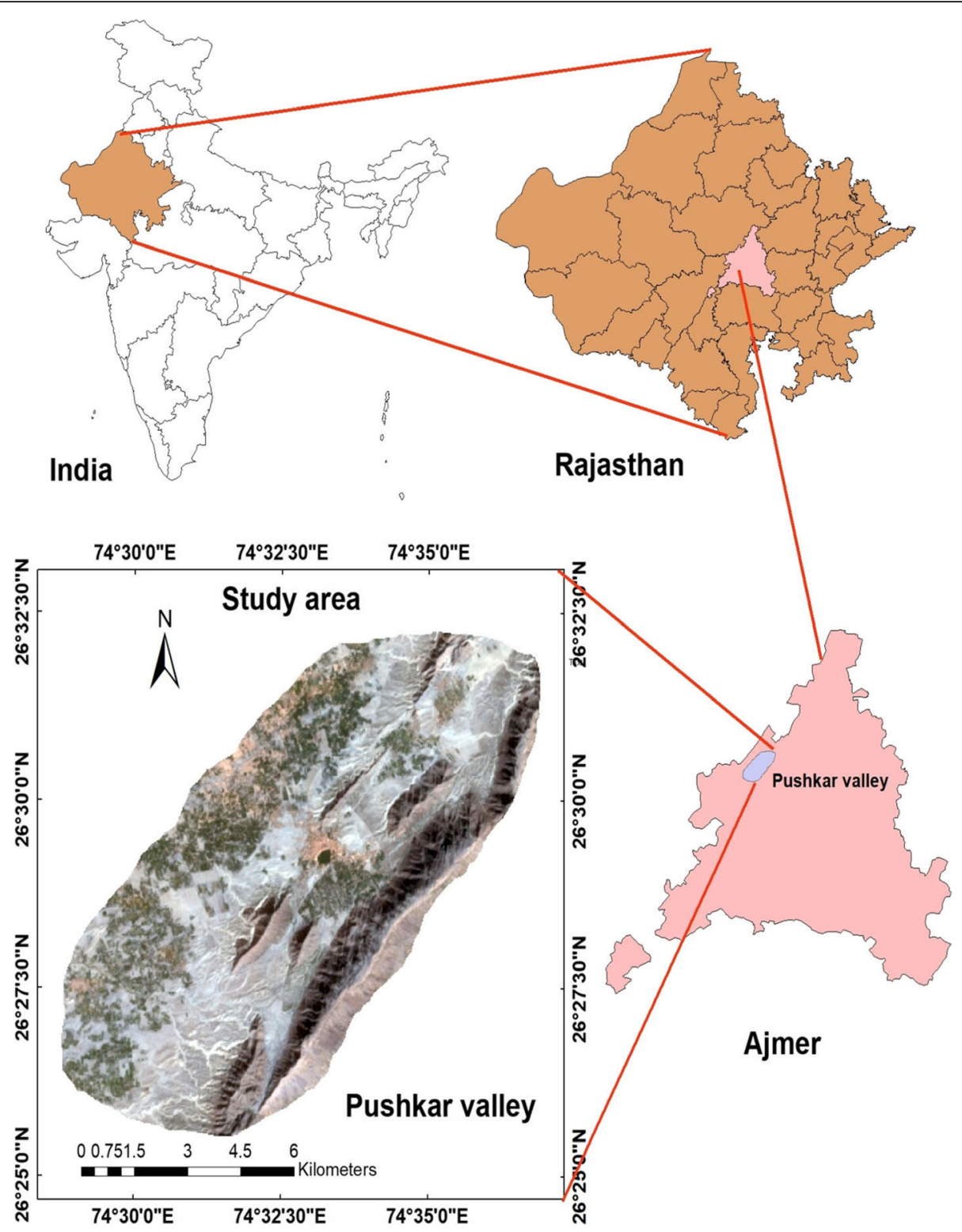

Fig. 1 Location map of Pushkar valley

was to determine land use change dynamics by using satellite images from 1993 to 2014, and to assess effect of land use changes on soil carbon stock in Pushkar valley region of Rajasthan.

\section{Materials and methods}

\section{Description of study site}

The study was carried in the Pushkar valley region $\left(26^{\circ}\right.$ $24^{\prime}$ to $26^{\circ} 33^{\prime} \mathrm{N}$ and $74^{\circ} 27^{\prime}$ to $74^{\circ} 40^{\prime} \mathrm{E}$ ) located in the center of Rajasthan State at a distance of $10 \mathrm{~km}$ northwest to Ajmer. Area covered by the Pushkar valley is about $97.93 \mathrm{~km}^{2}$. Location map of Pushkar valley is shown in Fig. 1. The valley is situated at an altitude of
$500 \mathrm{~m}$ above sea level. The average maximum temperature in summer ranges from 30.8 to $39.5{ }^{\circ} \mathrm{C}$ and average minimum temperature in summer ranges from 15.7 to $27.6{ }^{\circ} \mathrm{C}$. The average maximum temperature in winter ranges from 22.3 to $25.4{ }^{\circ} \mathrm{C}$ and average minimum temperature in winter ranges from 7.4 to $9.9{ }^{\circ} \mathrm{C}$. The mean annual rainfall is $450-527 \mathrm{~mm}$. Average precipitation is minimum in February $(1 \mathrm{~mm})$ and average precipitation is maximum in July $(195 \mathrm{~mm})$. The Pushkar Valley represents different soil types ranging from sandy clay to sandy loam. Soil has sand as major fraction and poor organic matter. $\mathrm{pH}$ values for all soils are on alkaline side (7.4 to 8$)$. 
The Pushkar Valley region forms the main part of Central Aravallis and represents an ecotone between North-West arid and South-East semi-arid agroclimatic zone of Rajasthan. The area of Pushkar Valley is represented by a long track of dense forest commonly known as "Nagpahar". The area represents a wide spectrum of habitats such as Aravalli hillocks, sand dunes, sandy plains, scrub forest, dense forest of Nagphar, agricultural fields, fresh water bodies (amphibious to perennial), rural to urban settlement, and mining land. Land use pattern observed in the study area are dry deciduous forest, tropical thorn forest, scrubland, agricultural cropland, agricultural plantation, agricultural fallow land, water body, settlement, and wasteland. The major ecological problems of Pushkar Valley region includes degradation of landscape and loss of natural soil surface due to deforestation of dense stands of nagpahar, intense agricultural activities, and mining excavations.

\section{Data acquisition and collection}

A Landsat thematic mapper (TM), enhanced thematic mapper plus (ETM+), and OLI/TIRS satellite image of Pushkar Valley region acquired in 1993, 2003, and 2014 respectively were obtained from the U.S. Geological Survey (USGS earth explorer). Characteristics of Landsat data are shown in Table 1. Images were downloaded in Geo-TIFF format with the different spectral bands as separate files. Topographic data in the form of maps (scale 1:50000) published by the Survey Department of the Government of India, were used as a geographical reference.

Ancillary data include ground reference data (often called ground truth data) collected from actual ground surveys collected independently. A Garmin global positioning system (GPS) V unit was used to verify the ground truth information collected during the field work in 2014 and recorded visible and other physical characteristics of the terrain for mapping purposes. Secondary data collected from local area and provided information on land use and land use conversion was also utilized in the study.

\section{Image pre-processing}

The datasets were imported into ArcMap 10.2 and individual bands of each of the three images (Landsat TM and Landsat ETM+, and Landsat OLI/TIRS) were combined into single composite image using the composite

Table 1 Characteristics of remote sensing images

\begin{tabular}{llll}
\hline Year & Satellite & Sensor & Date acquired \\
\hline 1993 & Landsat 4-5 & TM & $30 / 12 / 1993$ \\
2003 & Landsat 7 & ETM+ & 16/01/2003 \\
2014 & Landsat 8 & OLI/TIRS & 24/12/2014 \\
\hline
\end{tabular}

Bands tool in the Raster processing toolbar of ArcGIS 10.2. In Landsat TM and ETM+ images, all the bands were stacked together and band 6 which signifies thermal reflectance having spatial resolution of $120 \mathrm{~m}$ was excluded. Due to various external and internal conditions, some errors are caused in data. The pre-processing steps enhance the quality of data by removing or rectifying these errors. This is also known as data correction. There are two processes in data correction, i.e., geometric correction and radiometric condition.

\section{Geometric correction and area of interest extraction}

Geometric correction also known as geo-referencing means to give satellite images an actual coordinated system by eliminating the geometric distortions visible on the original remotely sensed images. Generally, satellite databases have different coordinate systems and therefore, it is necessary to geometrically correct the data and fit it into the original coordinate system. All the datasets (Landsat TM and Landsat ETM+, and Landsat OLI/TIRS) were georeferenced (Universal Transverse Mercator-UTM, WGS84) using linear transformation based on ground control points (GCPs) of the digital topographic maps. The outline of the Pushkar valley region was digitized on the basis of topographic map sheet and subset of image or area of interest delineated from the whole individual images for the respective years using extract by mask tool in the spatial analyst toolbar.

\section{Image classification and accuracy assessment}

The images were classified using the technique of supervised classification. Training samples is created in training sample manager and the definition of the training areas was supported by the topographic map sheet, visual interpretation of the satellite images in Google earth and by ground truthing. Firstly, 5-6 training samples were defined for sub-classes of each main land use type. The training samples were then merged of each land use category. Signature file of training sample is then created and finally classification is done by maximum likelihood classification. Accuracy has been assessed from ground truth data by generating random points and comparing it to classified map by developing confusion matrix. Overall accuracy was $87.81 \%, 93.3 \%$, and $95.4 \%$ for the classified images of the year 1993, 2003, and 2014 respectively (Table 5).

\section{Land use change analysis}

To assess the internal trading of land use classes, the vector datasets of these 3 years were intersected using intersect tool of ArcMap 10.2. The datasets obtained in this way were then exported in Excel and land use change matrix is prepared using pivot table and datasets 
were recorded into stable or converted land areas. Steps for land use change detection are presented in Fig. 2.

\section{Soil sampling and analysis}

In October 2014, three replicate sampling plots of dimension $5 \times 5 \mathrm{~m}$ were selected in each land-use type namely dry deciduous forest, tropical thorn forest, scrubland, agricultural crop land, agricultural plantation, and agricultural fallow land. Soil samples were collected at $0-10 \mathrm{~cm}, 10-20 \mathrm{~cm}$, and $20-30 \mathrm{~cm}$ depths from each corner of plot using auger and composite were made for each depth. Total number of composite samples collected from six land use and three soil depth was 54. Samples were then dried and sieved for analysis in the laboratory. Bulk density was estimated using core sampler (auger) (Blake and Harte 1986) and soil organic carbon determined by Walkley and Blake method (Allison 1975).

\section{Soil carbon stock calculation and effect of land use} changes

Following the Intergovernmental Panel on Climate Change (IPCC) guidelines, the SOC stock was calculated for soil to a depth of $30 \mathrm{~cm}$. Data collected from field survey in 2014 was used to calculate SOC stock for 2014. To calculate SOC stock for each sampling depth, i.e., $0-10,10-20$, and 10-20 cm, Eq. 1 was used given by Wairiu and Lal 2003.

$$
\mathrm{SOC}=(\mathrm{C} \text { content }) \times \mathrm{BD} \times 100
$$

Where, SOC $=$ soil organic carbon stock $\left(\mathrm{g} \mathrm{m}^{-2}\right)$

$\mathrm{C}$ content $=$ soil organic carbon $(\%)$

$\mathrm{BD}=$ soil bulk density $\left(\mathrm{g} \mathrm{cm}^{-3}\right)$

$d=$ soil layer thickness $(\mathrm{cm})$

Summation of carbon stock in each soil depth gives the total $\mathrm{C}$ pool in each land use type of the region. The carbon pool (Mt C) in all land use types was calculated

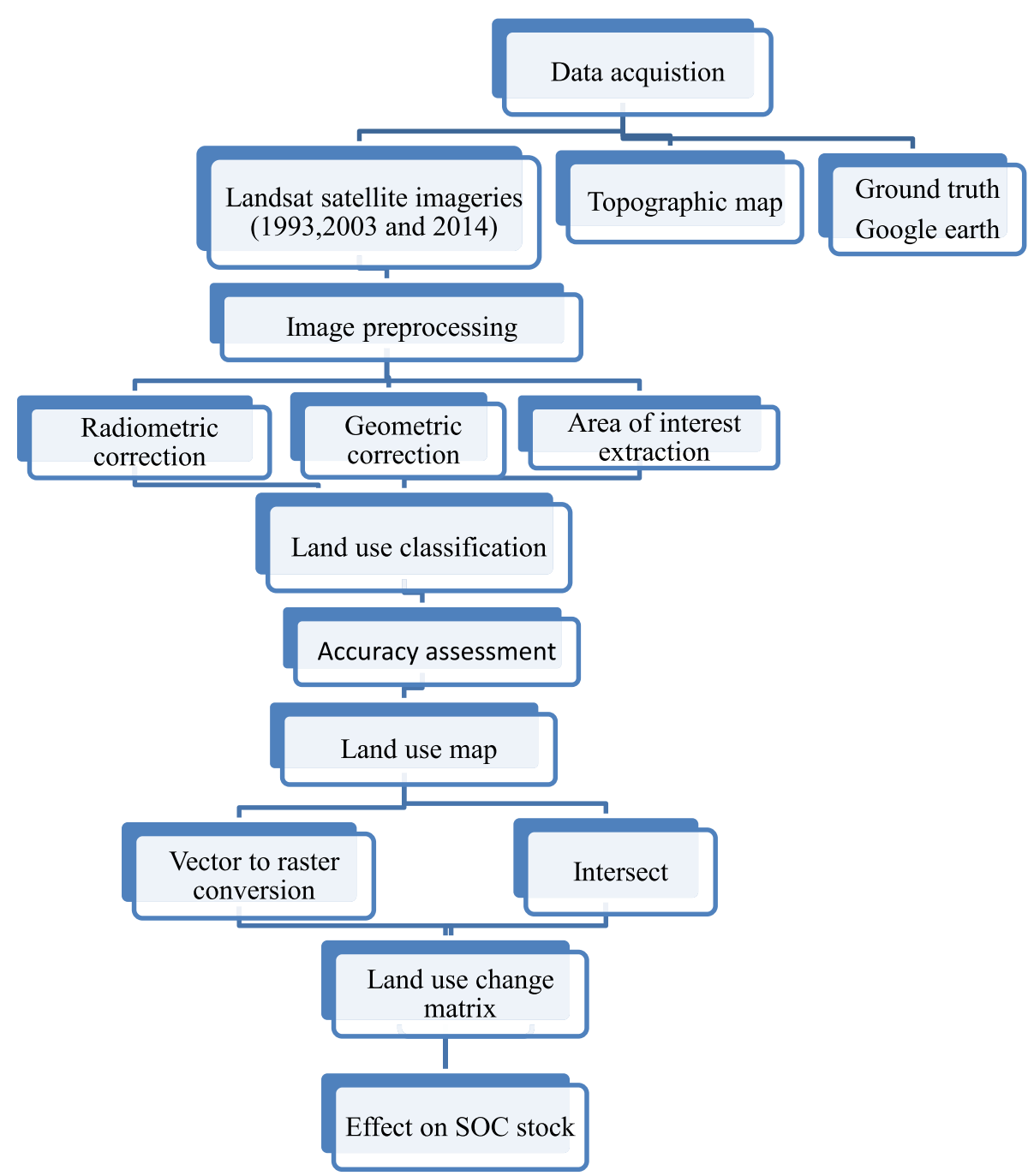

Fig. 2 Scheme for detection of land use change 
by multiplication of the carbon stock in each unit area ( $t /$ ha) with the total area covered by a specific land use. The SOC stock for previous year 1993 and 2003 were estimated using equation given by IPCC 2003.

$$
\mathrm{SOC}=\mathrm{SOC}_{\mathrm{REF}} \times \mathrm{EF}=\text { land } \mathrm{u}
$$

$\mathrm{SOC}_{\mathrm{REF}}=$ default reference carbon stock $(\mathrm{t} / \mathrm{ha})$

FLU = stock change factor for a specific land-use pattern (dimensionless)

FMG = stock change factor for management practice (dimensionless)

FI = stock change factor for organic matter input (dimensionless)

$\mathrm{SOC}_{\mathrm{REF}}$ default value for the tropical dry area is $38 \mathrm{t} \mathrm{C}$ $\mathrm{ha}^{-1}$. The SOC stock estimated for forest types (dry deciduous forest, thorn forest, and scrubland) in our study region varied from 24.91 to $37.78 \mathrm{t} \mathrm{C} \mathrm{ha}^{-1}$ which is lower than the $\mathrm{SOC}_{\mathrm{REF}}$ default value of IPCC (Table 2). Thus, we used our estimated values as the $\mathrm{SOC}_{\mathrm{REF}}$ for the forest area. Default reference soil organic carbon $\left(\mathrm{SOC}_{\mathrm{REF}}\right)$ for agricultural land (cropland, plantation, and fallow land) was determined by calculating mean value of the default $\mathrm{SOC}_{\mathrm{REF}}$ for three types of forest. The SOC stock change factors (FLU, FMG, and FI) were used from IPCC 2006 (Table 3), depending on land use management practices as mentioned by farmers and local people during field visit. The effect of internal trading of land uses on SOC stock was determined by calculating change in SOC stock ( $\mathrm{t} / \mathrm{ha}$ ) by deducting the base-year SOC stock from the final year stock of a particular land use conversion. Change in SOC stock (MTC) was determined by multiplying change in area (ha) with the change in SOC stock ( $t / h a)$ of each land use conversion. Scheme to determine effect of land use change on SOC stock is shown in Fig. 3.

\section{Results}

Land use/land cover change pattern analysis

Subset of satellite imageries and land use maps for 1993, 2003, and 2014 are presented in Fig. 4 and Fig. 5 respectively and land use/land use change pattern is shown in Table 4. During the period of 1993-2003, dry deciduous forest and tropical thorn forest was decreased by $1.34 \%$ and $28.94 \%$ respectively. Dry deciduous forest and tropical thorn forest decreased again during 20032014 by $4.15 \%$ and $15.82 \%$ respectively, accounting for the total decrease of $5.43 \%$ and $40.19 \%$ respectively in 2014 as compared to the area in 1993. Scrubland was increased in the first half (1993-2003) by $12.89 \%$ and decreased in second half (2003-2014) by $39.44 \%$ resulting in total decrease of 31.63\% in 2014 from 1993 (Table 4).

Among the agriculture land, cropland increased significantly (254.56\%) in the period 1993-2003 and again increased by $2.49 \%$ during 2003-2014, accounting for the total significant increase of $263.39 \%$ in 2014 as compared to the area in 1993. Agricultural plantation increased steadily in each time period of 1993-2003 and $2003-2014$ by $14.46 \%$ and $65.07 \%$ respectively, accounting for the total significant increase of $88.94 \%$ in 2014 as compared to the area in 1993. While fallow land was decreased in the first half (1976-1989) by $31.66 \%$ and increased in second half (1989-2003) by $11.66 \%$, thus there was a net decrease of $23.69 \%$ during $1993-2014$. It is interesting to note that the area under settlement increased in each time period and significant increase (345.67\%) was observed in 1993-2014. Wasteland also increased significantly by $99.54 \%$ during 1993-2014. Overall, the result showed that the total area under agricultural lands was increased by $32.14 \%$ while that under forest was decreased by $23.14 \%$ during the time period of 1993-2014 (Table 4).

\section{Internal trading of land uses (1993-2003)}

Dry deciduous forest remained the same during 10 years (1993-2003) by 2507.49 ha. Similarly, thorn forest, scrubland, cropland, and plantation remained the same by 772.41 ha, 596.19 ha, 211.45 ha, and 286.66 ha respectively. The land use conversion matrix has been shown in Table 6. Dry deciduous forest changed to thorn forest by 182.64 ha. To some extent, dry deciduous forest was changed to fallow land (21.68 ha),

Table 2 Default reference soil organic carbon stocks $\left(S O C_{R E F}\right)$ in different forest types at 0-30 cm depth (t/ha)

\begin{tabular}{|c|c|c|c|c|c|c|}
\hline Region & HAC soils & LAC soils & Sandy soils & Spodic soils & Volcanic soils & Wetland soils \\
\hline Boreal & 68 & NA & 10 & 117 & 20 & 146 \\
\hline Cold temperate, dry & 50 & 33 & 34 & NA & 20 & 87 \\
\hline Cold temperate, moist & 95 & 85 & 71 & 115 & 130 & \\
\hline Warm temperate, dry & 38 & 24 & 19 & NA & 70 & 88 \\
\hline Warm temperate, Moist & 88 & 63 & 34 & NA & 80 & \\
\hline Tropical, dry & 38 & 35 & 31 & NA & 50 & 86 \\
\hline Tropical, moist & 65 & 47 & 39 & NA & 70 & \\
\hline Tropical, wet & 44 & 60 & 66 & NA & 130 & \\
\hline
\end{tabular}

Source: IPCC (2006) 
Table 3 Relative stock change factors (FLU, FMG, and FI) (over 20 years) for different management activities on cropland

\begin{tabular}{|c|c|c|c|c|}
\hline Factor value type & Level & Temperature regime & Moisture regime & GPG revised default \\
\hline \multirow[t]{4}{*}{ Land use (FLU) } & \multirow[t]{4}{*}{ Long-term cultivated } & \multirow[t]{2}{*}{ Temperate } & Dry & 0.82 \\
\hline & & & Wet & 0.71 \\
\hline & & \multirow[t]{2}{*}{ Tropical } & Dry & 0.69 \\
\hline & & & Wet & 0.58 \\
\hline Land use (FLU) & Paddy rice & Temperate and tropical & Dry and wet & 1.1 \\
\hline \multirow[t]{2}{*}{ Land use (FLU) } & \multirow[t]{2}{*}{ Set aside (<20 years) } & \multirow[t]{2}{*}{ Temperate and tropical } & Dry & 0.93 \\
\hline & & & Wet & 0.82 \\
\hline \multirow[t]{2}{*}{ Tillage (FMG) } & \multirow[t]{2}{*}{ Full } & Temperate & Dry and wet & 1.0 \\
\hline & & Tropical & Dry and wet & 1.0 \\
\hline \multirow[t]{4}{*}{ Tillage (FMG) } & \multirow[t]{4}{*}{ Reduced } & \multirow[t]{2}{*}{ Temperate } & Dry & 1.03 \\
\hline & & & Wet & 1.09 \\
\hline & & \multirow[t]{2}{*}{ Tropical } & Dry & 1.10 \\
\hline & & & Wet & 1.16 \\
\hline \multirow[t]{4}{*}{ Tillage (FMG) } & \multirow[t]{4}{*}{ No-till } & \multirow[t]{2}{*}{ Temperate } & Dry & 1.10 \\
\hline & & & Wet & 1.16 \\
\hline & & \multirow[t]{2}{*}{ Tropical } & Dry & 1.17 \\
\hline & & & Wet & 1.23 \\
\hline \multirow[t]{4}{*}{ Input (FI) } & \multirow[t]{4}{*}{ Low } & \multirow[t]{2}{*}{ Temperate } & Dry & 0.92 \\
\hline & & & Wet & 0.91 \\
\hline & & \multirow[t]{2}{*}{ Tropical } & Dry & 0.92 \\
\hline & & & Wet & 0.91 \\
\hline \multirow[t]{2}{*}{ Input (FI) } & \multirow[t]{2}{*}{ Medium } & Temperate & Dry and wet & 1.0 \\
\hline & & Tropical & Dry and wet & 1.0 \\
\hline \multirow[t]{2}{*}{ Input (FI) } & \multirow[t]{2}{*}{ High-without manure } & \multirow[t]{2}{*}{ Temperate and tropical } & Dry & 1.07 \\
\hline & & & Wet & 1.11 \\
\hline \multirow[t]{2}{*}{ Input (FI) } & \multirow[t]{2}{*}{ High-with manure } & \multirow[t]{2}{*}{ Temperate and tropical } & Dry & 1.34 \\
\hline & & & Wet & 1.38 \\
\hline
\end{tabular}

Source: IPCC Good Practice Guidance for LULUCF, 2003

scrubland (8.39 ha), plantation (2.51 ha), and cropland (0.43 ha). Thorn forest change remarkably to scrubland by 826.30 ha. Also, thorn forest converted to cropland (169.80 ha), fallow land (259.55 ha), wasteland (66.76 ha), and plantation (6.98 ha). Scrubland was changed to thorn forest contributing area of 415.45 ha and also scrubland converted to fallow (178.18 ha), wasteland ( $92.77 \mathrm{ha})$, dry deciduous (30.72 ha), and cropland (40.33 ha). Cropland was changed to plantation and fallow land contributing area of 101.64 ha and 80.64 ha respectively, whereas plantation was changed to cropland and fallow land contributing area of 144.91 ha and 100.18 ha respectively. The remarkable change on fallow land was seen which was converted to cropland contributing area of 919.85 ha. Also, fallow land converted to plantation (180.84 ha), thorn forest (121.32 ha), dry deciduous forest (89.06 ha), scrubland (66.81 ha), and settlement (21.80).

\section{Internal trading of land uses (2003-2014)}

Land under dry deciduous forest remained consistent during 10 years (2003-2014) by 2493.35 ha. Similarly, land under thorn forest, scrubland, cropland, and plantation remained the same by 912.73 ha, 608.34 ha, 762.40 ha, and 361.83 ha respectively. Dry deciduous forest changed to thorn forest by 74.65 ha. The remarkable change on thorn forest to scrubland was seen which contributed by 255.93 ha. The land use conversion matrix has been shown in Table 7. Dry deciduous forest was changed to fallow land (60.09 ha), scrubland (21.29 ha), plantation (17.22 ha), and cropland (14.32 ha). Thorn forest was converted to wasteland (129.96 ha), fallow land (108.80 ha), dry deciduous forest $(58.05 \mathrm{ha})$, and cropland (24.53 ha). The remarkable change on scrubland was seen which was converted to thorn forest contributing an area of 


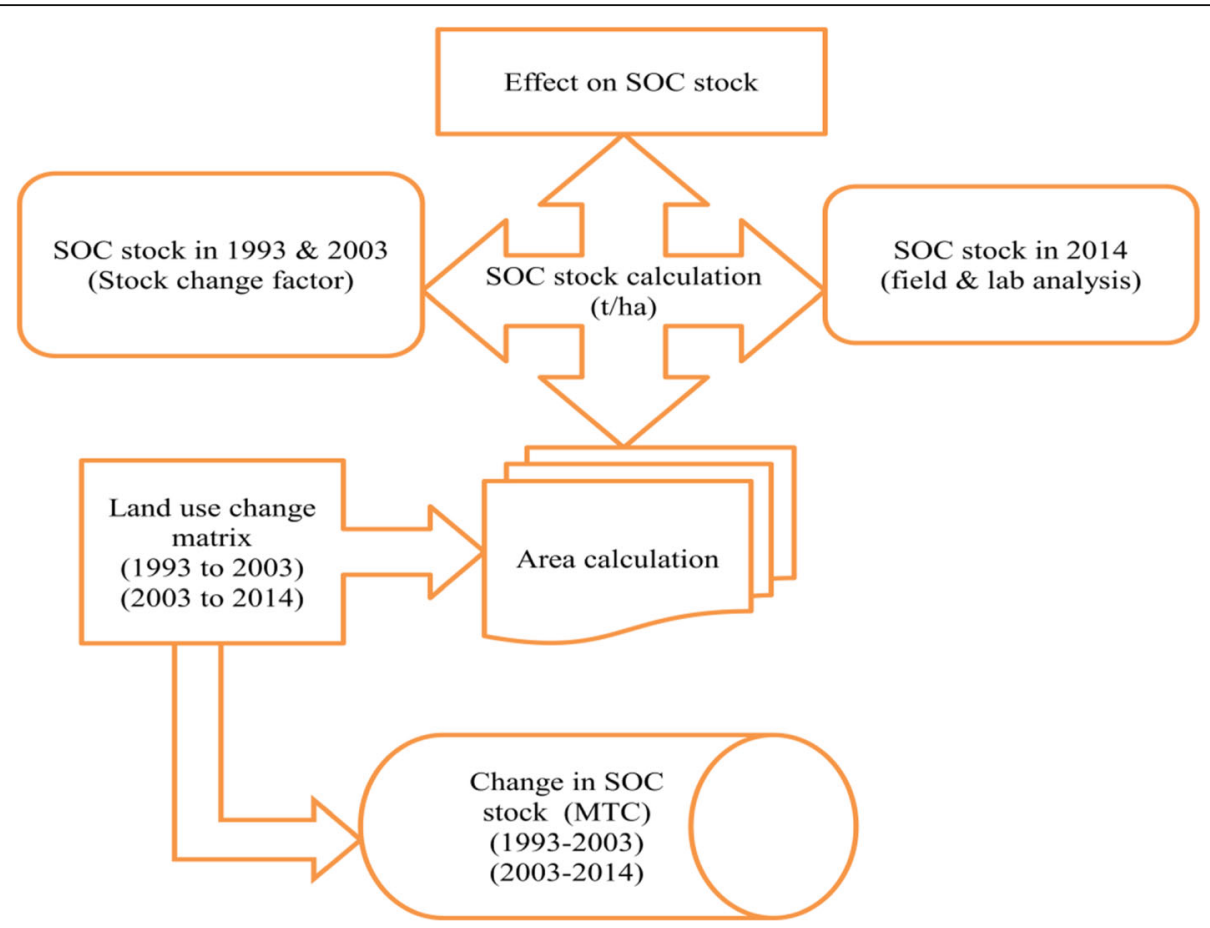

Fig. 3 Scheme to determine effect of Land use change on SOC stock
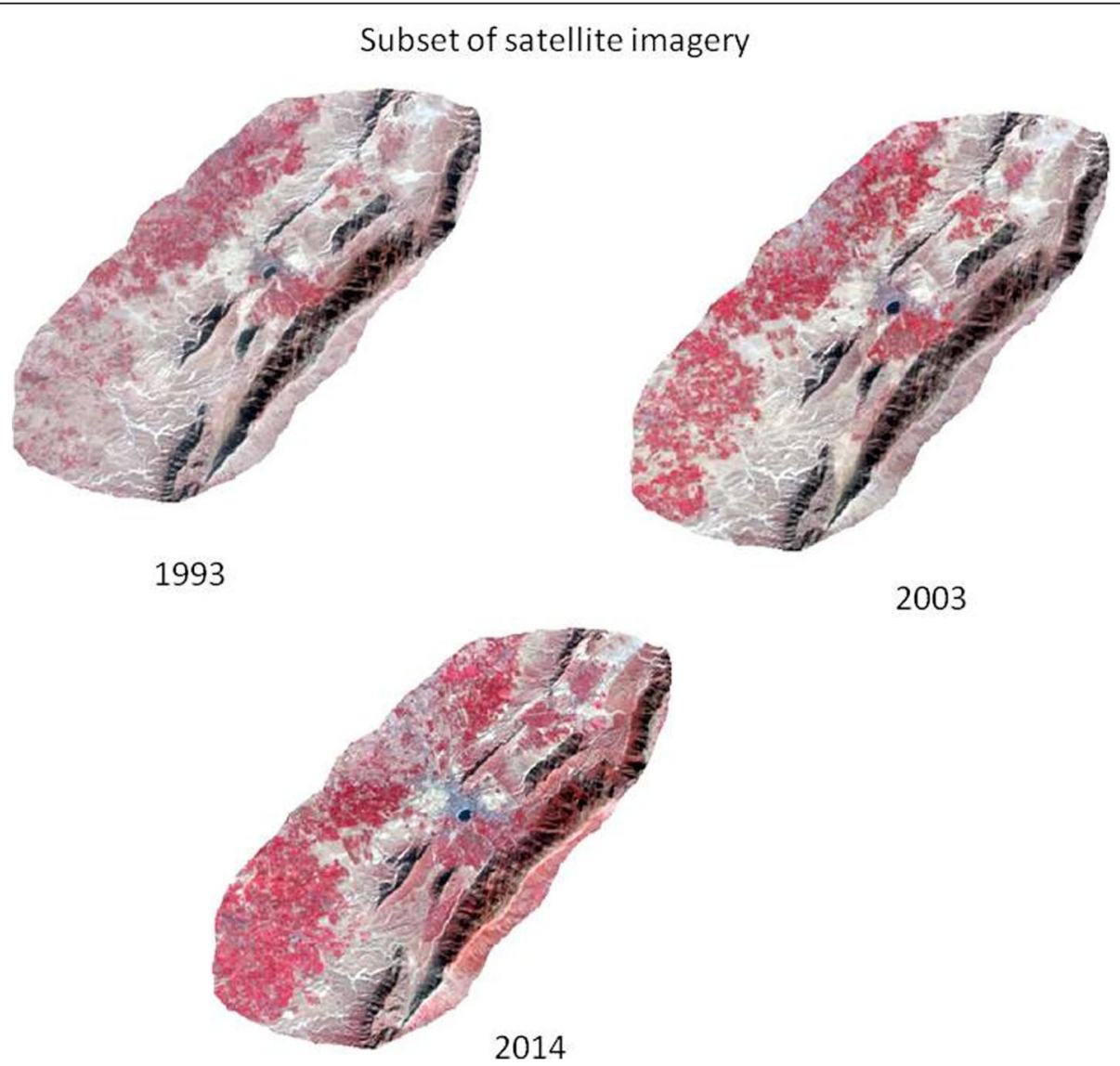

2003

Fig. 4 Subset of multispectral satellite imageries (1993-2014) 

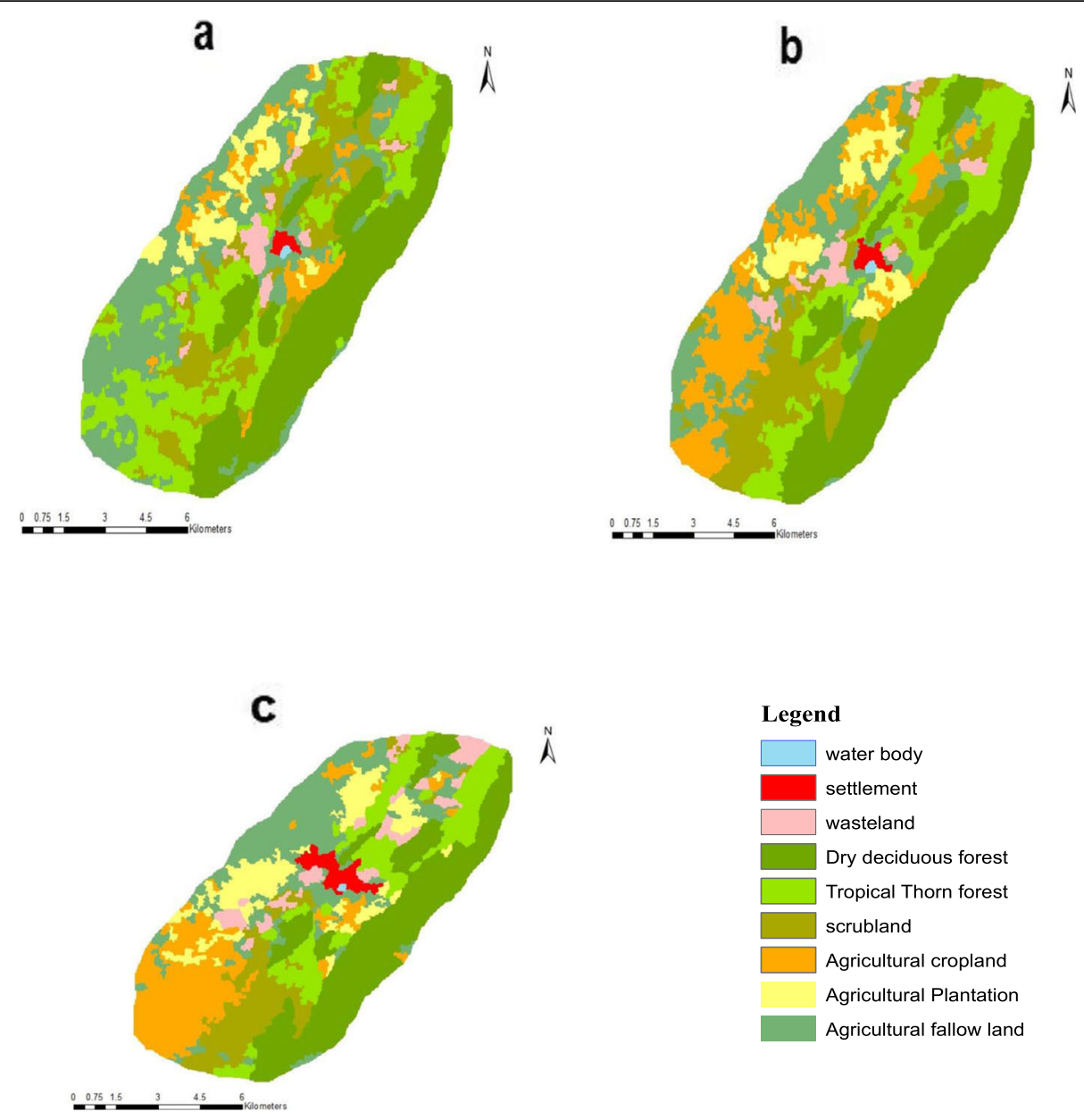

Legend

$\AA^{N}$

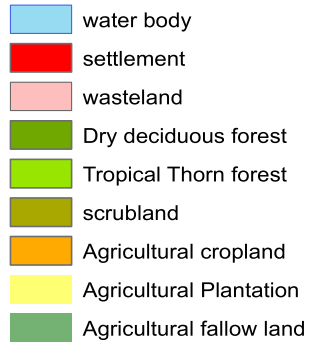

Fig. 5 Land use land cover maps of a 1993, b 2003, and c 2014

254.15 ha, cropland (242.97 ha), wasteland (204.73 ha), fallow land (163.35 ha), and plantation (48.69 ha). The major change was the conversion of cropland to plantation and fallow land contributing an area of 370.95 ha and 330.59 ha respectively, whereas plantation was changed to fallow and crop land contributing an area of 191.43 ha and 52.52 ha respectively. Fallow land changed remarkably to cropland contributing an area of 416.58 ha. Also, fallow land was converted to plantation (181.99 ha), wasteland (73.78 ha), thorn forest (28.88 ha), dry deciduous forest (16.57 ha), and wasteland (14.55 ha).

Table 4 Land use/land use change patterns (1993-2014)

\begin{tabular}{|c|c|c|c|c|c|c|}
\hline \multirow[t]{2}{*}{ Land use type } & \multirow{2}{*}{$\begin{array}{l}1993 \\
\text { Area (ha) }\end{array}$} & \multirow{2}{*}{$\begin{array}{l}2003 \\
\text { Area (ha) }\end{array}$} & \multirow{2}{*}{$\begin{array}{l}2014 \\
\text { Area (ha) }\end{array}$} & \multicolumn{3}{|c|}{ Change in area (ha) } \\
\hline & & & & 1993-2003 & 2003-2014 & 1993-2014 \\
\hline Water body & 10.08 & 12.24 & 7.65 & 2.16 & -4.59 & -2.43 \\
\hline Settlement & 44.73 & 69.48 & 199.35 & 24.75 & 129.87 & 154.62 \\
\hline Wasteland & 254.7 & 284.76 & 508.23 & 30.06 & 223.47 & 253.53 \\
\hline Dry deciduous & 2725.2 & 2688.75 & 2577.15 & -36.45 & -111.6 & -148.05 \\
\hline Tropical thorn & 2149.92 & 1527.66 & 1285.92 & -622.26 & -241.74 & -864 \\
\hline Scrubland & 1372.14 & 1548.99 & 938.07 & 176.85 & -610.92 & -434.07 \\
\hline Cropland & 420.66 & 1491.48 & 1528.65 & 1070.82 & 37.17 & 1107.99 \\
\hline Plantation & 532.17 & 609.12 & 1005.48 & 76.95 & 396.36 & 473.31 \\
\hline Fallow land & 2283.57 & 1560.69 & 1742.67 & -722.88 & 181.98 & -540.9 \\
\hline
\end{tabular}


Table 5 Accuracy assessment of classified map of 3 years

\begin{tabular}{|c|c|c|c|c|c|c|}
\hline \multirow[b]{2}{*}{ Land use types } & \multicolumn{2}{|l|}{1993} & \multicolumn{2}{|l|}{2003} & \multicolumn{2}{|l|}{2014} \\
\hline & $\begin{array}{l}\text { User's accuracy } \\
\text { (\%) }\end{array}$ & $\begin{array}{l}\text { Producer's accuracy } \\
\text { (\%) }\end{array}$ & $\begin{array}{l}\text { User's accuracy } \\
(\%)\end{array}$ & $\begin{array}{l}\text { Producer's accuracy } \\
(\%)\end{array}$ & $\begin{array}{l}\text { User's accuracy } \\
\text { (\%) }\end{array}$ & $\begin{array}{l}\text { Producer's accuracy } \\
(\%)\end{array}$ \\
\hline Water body & 100 & 100 & 100 & 100 & 100 & 100 \\
\hline Settlement & 100 & 100 & 100 & 100 & 100 & 100 \\
\hline Wasteland & 97 & 95.09 & 95 & 96.3 & 96 & 96.8 \\
\hline Dry deciduous & 94 & 98.94 & 96 & 98.9 & 97.4 & 99 \\
\hline Tropical thorn & 72 & 94.73 & 82 & 95.6 & 83.7 & 96.4 \\
\hline Scrubland & 94 & 79.66 & 95 & 84.7 & 96.2 & 86.9 \\
\hline Cropland & 66.3 & 79.77 & 78 & 88.6 & 79.6 & 89.4 \\
\hline Plantation & 93.6 & 66.07 & 92.3 & 74.5 & 94.5 & 78.7 \\
\hline Fallow & 78.4 & 82.35 & 79.4 & 79.4 & 81.3 & 85.9 \\
\hline $\begin{array}{l}\text { Overall accuracy } \\
(\%)\end{array}$ & 87.81 & & 93.3 & & 95.4 & \\
\hline Kappa coefficient & 0.85 & & 0.89 & & 0.91 & \\
\hline
\end{tabular}

\section{Land use change dynamics}

Major land use change dynamics in 1993-2003, 20032014, and 1993-2014 is shown in the map in Fig. 6. Also, major land use change dynamics in percentage is presented in Table 8 . Changes between forest types in 1993-2003 and $2003-2014$ are $14.14 \%$ and $6.84 \%$ respectively. Changes from agricultural land to forest are $4.98 \%$ and $0.86 \%$ during 1993-2003 and 2003-2014 respectively. In both the periods (1993-2003 and 20032014), $7 \%$ of forest area is converted to agricultural land and about $15 \%$ changes occurred among agricultural land. About $60 \%$ of the area remains the same in both the periods.

\section{Change in soil organic carbon stock}

Net change in SOC pool within 21 years from 1993-2014 is shown in Table 9. SOC stock in forest land was found higher than agricultural land based on field data collected in 2014. Among different forest types, maximum soil carbon stock is found in dry deciduous forest (37.78 t/ha) followed by thorn forest $(28.41 \mathrm{t} / \mathrm{ha})$, and minimum in scrubland $(24.91 \mathrm{t} / \mathrm{ha})$. Our results revealed that there is significant temporal change in the SOC stock under agricultural lands (cropland, plantation, and fallow land) during 1993-2014 period. Changes in SOC stock were highest in the fallow land, with decrease of $8.41 \mathrm{t} / \mathrm{ha}$ in the periods 1993-2014 (Table 9). Also, there is increase of SOC pool by $2.27 \mathrm{t} / \mathrm{ha}$ and $4.05 \mathrm{t} / \mathrm{ha}$ in cropland and plantation respectively in the period 1993-2014. There is a net decrease in SOC from 1993 to 2014. In 1993, total SOC of all land use types was $287.16 \mathrm{Mt} \mathrm{C}$ and in 2003 total SOC was $276.04 \mathrm{Mt} \mathrm{C}$, and in 2014 total SOC was $260.08 \mathrm{Mt} \mathrm{C}$ (Table 9).

In the period 1993-2003, SOC pool changes were highest in fallow land and cropland with decrease of 24.71 Mt C under fallow land and increase of $24.63 \mathrm{Mt} \mathrm{C}$ under cropland (Table 9). In the period 2003-2014, SOC pool changes were observed remarkably in fallow land (-30.12 Mt C), cropland (26.68 Mt C), and thorn forest (-24.55 Mt C).

Table 6 Land use change matrix (1993-2003)

\begin{tabular}{|c|c|c|c|c|c|c|c|c|c|c|}
\hline Land use & Water & Settlement & Wasteland & Dry deciduous & Thorn & Scrubland & Cropland & Plantation & Fallow & Total area in 1993 (ha) \\
\hline Water & 9.44 & 0.40 & & & & & & & 0.09 & 9.93 \\
\hline Settlement & 0.17 & 44.23 & & & & & & & 0.37 & 44.77 \\
\hline Wasteland & & & 114.81 & 5.27 & 28.73 & 38.84 & 2.70 & 15.72 & 48.07 & 254.14 \\
\hline Dry deciduous & & & & 2507.49 & 182.64 & 8.39 & 0.43 & 2.51 & 21.68 & 272.15 \\
\hline Thorn & & 1.71 & 66.76 & 44.74 & 772.41 & 826.30 & 169.80 & 6.98 & 259.55 & 2148.23 \\
\hline Scrubland & & 1.47 & 92.77 & 30.72 & 415.45 & 596.19 & 40.33 & 15.93 & 178.18 & 1371.05 \\
\hline Cropland & & & & 10.53 & 6.83 & 9.25 & 211.45 & 101.64 & 80.64 & 420.34 \\
\hline Plantation & & & & & & 0.98 & 144.91 & 286.66 & 100.18 & 532.74 \\
\hline Fallow & 2.61 & 21.80 & 10.70 & 89.06 & 121.32 & 66.81 & 919.85 & 180.84 & 868.25 & 2281.25 \\
\hline Total area in 2003(ha) & 12.22 & 69.61 & 285.04 & 2687.81 & 1527.38 & 1546.76 & 1489.47 & 610.28 & 1557.01 & 9785.6 \\
\hline
\end{tabular}


Table 7 Land use change matrix (2003-2014)

\begin{tabular}{|c|c|c|c|c|c|c|c|c|c|c|}
\hline Land use & Water & Settlement & Wasteland & Dry deciduous & Thorn & Scrubland & Cropland & Plantation & Fallow & Total area in 2003 (ha) \\
\hline Water & 7.09 & 3.57 & & & & & & & 0.16 & 12.23 \\
\hline Settlement & 0.16 & 67.32 & & & & & & & 2.13 & 69.61 \\
\hline Wasteland & & 11.88 & 136.83 & & 5.77 & 44.86 & 13.22 & 8.26 & 64.14 & 284.97 \\
\hline Dry deciduous & & 1.33 & 6.82 & 2493.35 & 74.65 & 21.29 & 14.32 & 17.22 & 60.09 & 2689.07 \\
\hline Thorn & & 21.11 & 129.96 & 58.05 & 912.73 & 255.93 & 24.53 & 16.25 & 108.80 & 1527.35 \\
\hline Scrubland & & 18.89 & 204.73 & 5.55 & 254.15 & 608.34 & 242.97 & 48.69 & 163.35 & 1546.67 \\
\hline Cropland & & & 13.80 & 1.27 & 9.23 & 0.82 & 762.40 & 370.95 & 330.59 & 1489.08 \\
\hline Plantation & & 1.92 & 0.11 & 2.14 & 0.12 & 0.19 & 52.52 & 361.83 & 191.43 & 610.28 \\
\hline Fallow land & & 73.78 & 14.55 & 16.57 & 28.88 & 8.03 & 416.58 & 181.99 & 816.37 & 1556.75 \\
\hline Total area in 2014(ha) & 7.25 & 199.81 & 506.80 & 2576.93 & 1285.52 & 939.46 & 1526.55 & 1005.21 & 1738.47 & 9786.01 \\
\hline
\end{tabular}
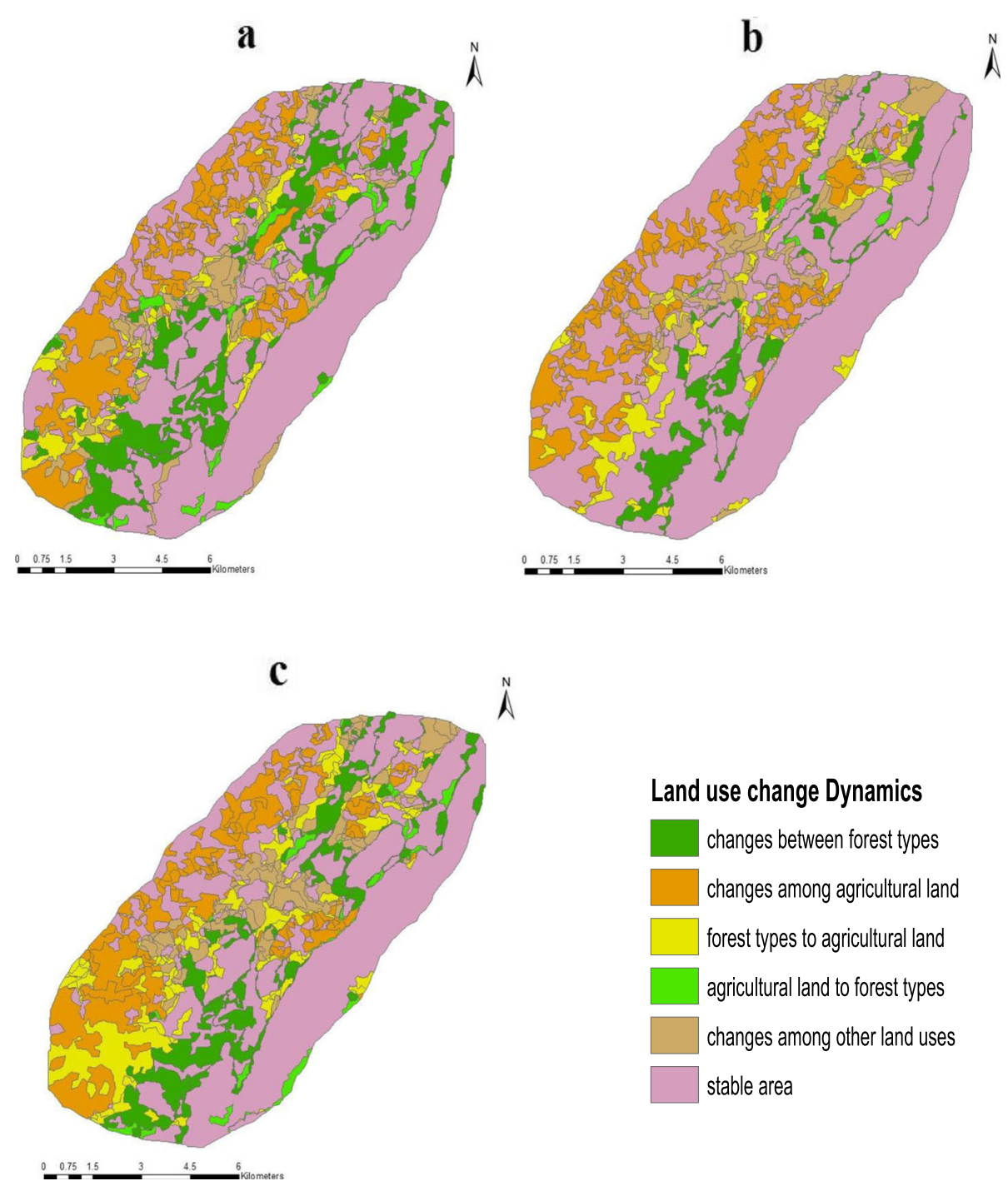

\section{Land use change Dynamics}

changes between forest types

changes among agricultural land

forest types to agricultural land

agricultural land to forest types

changes among other land uses

stable area

Fig. 6 Land use change dynamics in a 1993-2003, b 2003-2014, c 1993-2014 
Table 8 Land use change dynamics in 1993-2003 and 2003-2014

\begin{tabular}{lllll}
\hline Land use change dynamics & $1993-2003$ & & 2003-2014 \\
\cline { 2 - 3 } & Area (ha) & \% of total & & Area (ha) \\
\hline Changes between forest types & 1384.19 & 14.14 & 669.62 & 1544.06 \\
Changes among agricultural land & 1528.06 & 15.61 & 696.22 & 15.78 \\
Changes from forest to agricultural land & 695.39 & 7.11 & 83.8 & 6.11 \\
Changes from agricultural land to forest & 487.06 & 4.98 & 626.05 & 6.86 \\
Changes among other land uses & 279.97 & 2.86 & 6166.26 \\
Stable area & 5410.93 & 55.29 & & 63.01 \\
\hline
\end{tabular}

\section{Effect of internal trading of land use on SOC stock}

Changes in the SOC pools were observed due to changes in land use or land management practices. Change in SOC stock due internal trading of land use is presented in Table 10. During the period of 1993-2003, the rate of loss in SOC was observed higher when dry deciduous forest was changed to other land types, i.e., cropland (15.33 t/ha), scrubland (12.87 t/ha), fallow land (11.8 t/ ha), and thorn forest $(9.37 \mathrm{t} / \mathrm{ha})$. Conversion of thorn to scrubland results in loss of $2.89 \mathrm{Mt} \mathrm{C}$ soil carbon and conversion of dry deciduous forest to thorn forest results in $1.71 \mathrm{Mt} C$ soil carbon loss during the period 19932003. The maximum rate of gain in SOC during 19932003 was observed when cropland converted to dry deciduous forest $(16.83 \mathrm{t} / \mathrm{ha})$ followed by conversion of scrubland to dry deciduous (12.87 t/ha), cropland to plantation (9.42 $\mathrm{t} / \mathrm{ha}$ ), and conversion of thorn to dry deciduous $(9.37 \mathrm{t} / \mathrm{ha})$. Conversion of scrubland to thorn forest leads to maximum gain of $1.45 \mathrm{Mt} \mathrm{C}$ in 19932003. Effect of major land use change dynamics on SOC stock in 1993-2003 is shown in Figs. 7a and 8a, and it shows that changes among agricultural land leads to maximum loss of soil carbon, i.e., $4.88 \mathrm{Mt} \mathrm{C}$.

During the period of 2003-2014, the rate of loss in SOC was observed remarkably due to conversion of dry deciduous forest to other land use types, i.e., fallow (17.61 t/ha), cropland (14.56 t/ha), scrubland (12.87 t/ ha), and thorn forest (9.37 t/ha). Conversion of dry deciduous and plantation to fallow land leads to loss of $1.06 \mathrm{Mt} \mathrm{C}$ and $1.95 \mathrm{Mt} \mathrm{C}$. Also, there was a loss of 1.15 Mt $C$ soil carbon when fallow land was changed to cropland. Prominent rate of SOC gain in 2003-2014 was found due to conversion of cropland to dry deciduous forest $(15.36 \mathrm{t} / \mathrm{ha})$, scrubland to dry deciduous forest (12.87 t/ha), fallow to dry deciduous forest (11.8 t/ha), cropland to plantation $(9.57 \mathrm{t} / \mathrm{ha})$, and thorn forest to dry deciduous forest $(9.37 \mathrm{t} / \mathrm{ha})$. Conversion of cropland and fallow land to plantation results in gain of SOC by 3.55 and $1.09 \mathrm{Mt} C$ respectively. The estimated effects of other internal trading of land use changes are shown in Table 8. Effect of major land use change on SOC stock in 2003-2014 is shown in Figs. 7b and 8b, and it shows that conversion of forest to agricultural land leads to loss in $3.16 \mathrm{Mt} \mathrm{C}$ soil carbon.

\section{Discussion}

The total area under cultivated land was increased, while that under forest was decreased during the time periods under study (1993-2014). During this period, increase in human population leads to increase in demand of crop cultivation which results in deforestation. Also, this demand leads to the major conversion of fallow land to cropland during the period 1993-2014. During both the period, thorn forest change remarkably to scrubland.

Table 9 Net change in SOC pool within 21 years from 1993 to 2014

\begin{tabular}{|c|c|c|c|c|c|c|}
\hline \multirow[t]{2}{*}{ Land use } & \multicolumn{2}{|l|}{${ }^{a} 1993$} & \multicolumn{2}{|l|}{${ }^{\mathrm{a}} 2003$} & \multicolumn{2}{|l|}{${ }^{b} 2014$} \\
\hline & SOC (t/ha) & $\mathrm{SOC}(\mathrm{Mt} \mathrm{C})$ & SOC (t/ha) & $\mathrm{SOC}(\mathrm{Mt} \mathrm{C})$ & SOC (t/ha) & $\mathrm{SOC}(\mathrm{Mt} \mathrm{C})$ \\
\hline Dry deciduous forest & 37.78 & 102.96 & 37.78 & 101.58 & 37.78 & 97.36 \\
\hline Tropical thorn forest & 28.41 & 61.08 & 28.41 & 43.40 & 28.41 & 36.53 \\
\hline Scrubland & 24.91 & 34.18 & 24.91 & 38.58 & 24.91 & 23.37 \\
\hline Agricultural cropland & 20.95 & 8.81 & 22.42 & 33.44 & 23.22 & 35.49 \\
\hline Agricultural Plantation & 27.94 & 14.87 & 30.37 & 18.49 & 31.99 & 32.16 \\
\hline Agricultural fallow land & 28.58 & 65.26 & 25.98 & 40.55 & 20.17 & 35.14 \\
\hline Total & & 287.16 & & 276.04 & & 260.05 \\
\hline
\end{tabular}

${ }^{a}$ Based on IPCC guideline

${ }^{\mathrm{b}}$ Based on field data 
Table 10 Effect of internal trading of land use on SOC stock

\begin{tabular}{|c|c|c|c|c|c|c|}
\hline \multirow[t]{2}{*}{ Land use change } & \multicolumn{3}{|l|}{$1993-2003$} & \multicolumn{3}{|l|}{$2003-2014$} \\
\hline & $\begin{array}{l}\text { Change in } \\
\text { area (ha) }\end{array}$ & $\begin{array}{l}\text { Change in SOC } \\
\text { stock (t/ha) }\end{array}$ & $\begin{array}{l}\text { Change in SOC stock } \\
\text { (Mt C) }\end{array}$ & $\begin{array}{l}\text { Change in } \\
\text { area (ha) }\end{array}$ & $\begin{array}{l}\text { Change in SOC } \\
\text { stock (t/ha) }\end{array}$ & $\begin{array}{l}\text { Change in SOC stock } \\
\text { (Mt C) }\end{array}$ \\
\hline $\begin{array}{l}\text { Dry deciduous } \\
\text { to thorn forest }\end{array}$ & 182.64 & -9.37 & -1.71 & 74.65 & -9.37 & -0.69 \\
\hline $\begin{array}{l}\text { Dry deciduous } \\
\text { to scrubland }\end{array}$ & 8.39 & -12.87 & -0.11 & 21.29 & -12.87 & -0.27 \\
\hline $\begin{array}{l}\text { Dry deciduous } \\
\text { to cropland }\end{array}$ & 0.43 & -15.33 & -0.007 & 14.32 & -14.56 & -0.21 \\
\hline $\begin{array}{l}\text { Dry deciduous } \\
\text { to plantation }\end{array}$ & 2.51 & -7.41 & -0.02 & 17.22 & -5.79 & -0.09 \\
\hline $\begin{array}{l}\text { Dry deciduous } \\
\text { to fallow }\end{array}$ & 21.68 & -11.8 & -0.25 & 60.09 & -17.61 & -1.06 \\
\hline Thorn to dry deciduous & 44.74 & 9.37 & 0.42 & 58.05 & 9.37 & 0.54 \\
\hline Thorn to scrubland & 826.30 & -3.5 & -2.89 & 255.93 & -3.5 & -0.89 \\
\hline Thorn to cropland & 169.80 & -5.99 & -1.02 & 24.53 & -5.19 & -0.13 \\
\hline Thorn to plantation & 6.98 & 1.96 & 0.01 & 16.25 & 3.58 & 0.06 \\
\hline Thorn to fallow land & 259.55 & -2.43 & -0.63 & 108.80 & -8.24 & -0.89 \\
\hline $\begin{array}{l}\text { Scrubland to } \\
\text { dry deciduous }\end{array}$ & 30.72 & 12.87 & 0.39 & 5.55 & 12.87 & 0.07 \\
\hline $\begin{array}{l}\text { Scrubland to } \\
\text { thorn forest }\end{array}$ & 415.45 & 3.5 & 1.45 & 254.15 & 3.5 & 0.89 \\
\hline Scrubland to cropland & 40.33 & -2.49 & -0.07 & 242.97 & -1.69 & -.41 \\
\hline Scrubland to plantation & 15.93 & 5.46 & 0.10 & 48.69 & 7.08 & 0.34 \\
\hline $\begin{array}{l}\text { Scrubland to } \\
\text { fallow land }\end{array}$ & 178.18 & 1.07 & 0.19 & 163.35 & -4.74 & -0.77 \\
\hline $\begin{array}{l}\text { Cropland to } \\
\text { dry deciduous }\end{array}$ & 10.53 & 16.83 & 0.18 & 1.27 & 15.36 & 0.02 \\
\hline $\begin{array}{l}\text { Cropland to } \\
\text { thorn forest }\end{array}$ & 6.83 & 7.46 & 0.05 & 9.23 & 5.99 & 0.05 \\
\hline Cropland to scrubland & 9.25 & 3.96 & 0.04 & 0.82 & 2.49 & 0.002 \\
\hline Cropland to plantation & 101.64 & 9.42 & 0.96 & 370.95 & 9.57 & 3.55 \\
\hline $\begin{array}{l}\text { Cropland to } \\
\text { fallow land }\end{array}$ & 80.64 & 5.03 & 0.40 & 330.59 & -2.25 & -0.74 \\
\hline Plantation to scrubland & 0.98 & -3.03 & -0.003 & 0.19 & -5.46 & -0.001 \\
\hline Plantation to cropland & 144.91 & -5.52 & -0.79 & 52.52 & -7.15 & -0.37 \\
\hline $\begin{array}{l}\text { Plantation to } \\
\text { fallow land }\end{array}$ & 100.18 & -1.96 & -0.19 & 191.43 & -10.2 & -1.95 \\
\hline $\begin{array}{l}\text { Fallow to dry } \\
\text { deciduous forest }\end{array}$ & 89.06 & 9.2 & 0.82 & 16.57 & 11.8 & 0.19 \\
\hline Fallow to thorn forest & 121.32 & -0.17 & -0.02 & 28.88 & 2.43 & 0.07 \\
\hline Fallow to scrubland & 66.81 & -3.67 & -0.24 & 8.03 & -1.07 & -0.008 \\
\hline Fallow to cropland & 919.85 & -6.16 & -5.67 & 416.58 & -2.76 & -1.15 \\
\hline Fallow to plantation & 180.84 & 1.79 & 0.32 & 181.99 & 6.01 & 1.09 \\
\hline Total & & & -8.29 & & & -2.76 \\
\hline
\end{tabular}

The reason might be low rainfall during that period which leads to land degradation. During 2003-2014, it was also observed that in some area scrubland is converted to thorn forest which indicated an altogether positive effect of forest management by the local people since 2003.

SOC stock in forest land was found higher than agricultural land based on field data collected in 2014. The 

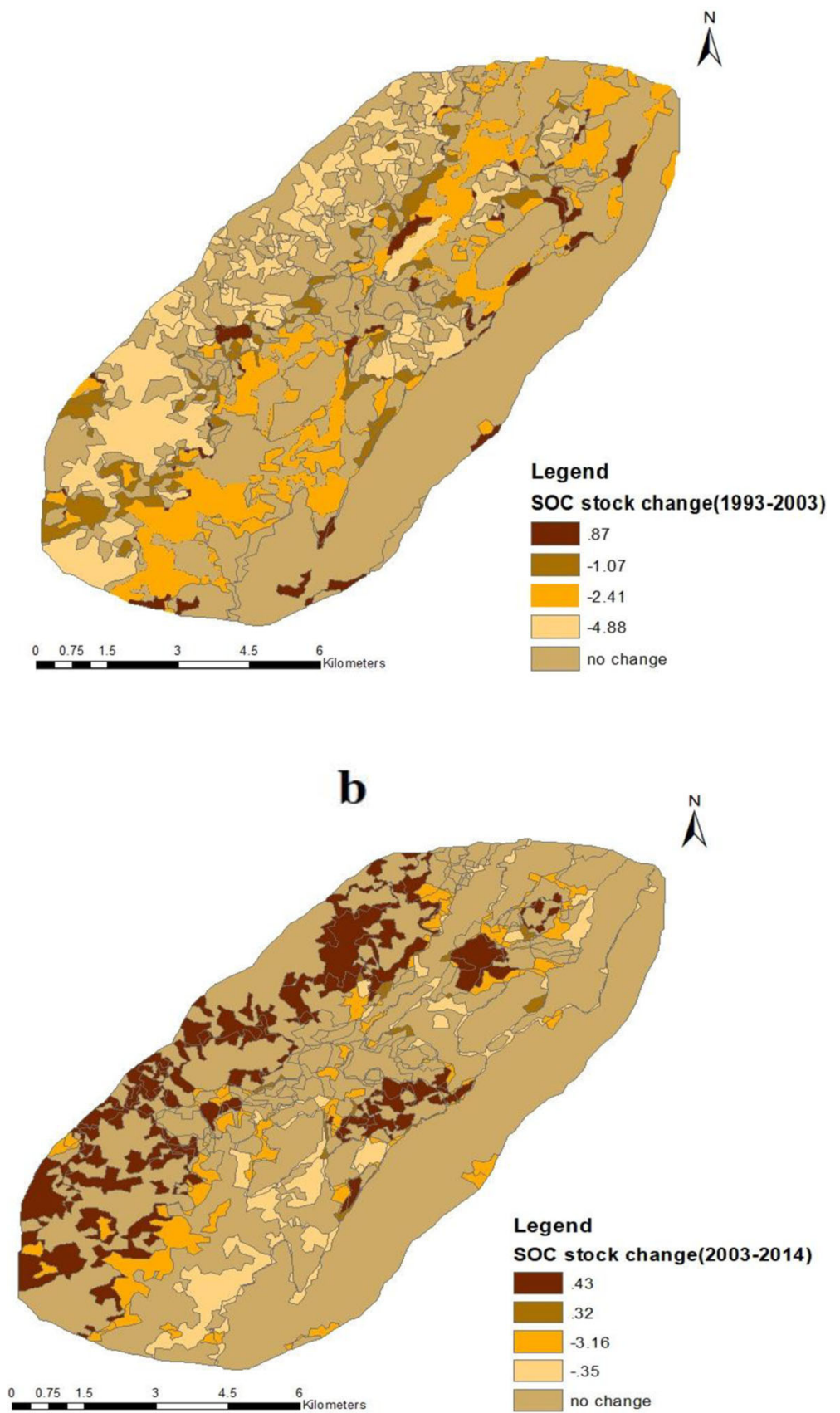

Fig. 7 Change in soil organic carbon stock (Mt C) in 0-30 cm depth due to land use change in a 1993-2003 and b 2003-2014

result is in harmony with findings from previous studies (Davidson and Ackerman 1993; Amundson 2001; Murty et al. 2002; Don et al. 2011). The reason for more soil carbon stock in the soil of forest is due to the minimum disturbance in soil and a slow rate of SOC decomposition which result in higher carbon accumulation, whereas low SOC stock in agricultural land is due to intensive cultivation practices which results in greater soil disturbance, and increase rate of SOC decomposition (Mancinelli et al. 2010; Sainju et al. 2008; Yimer et al. 2007). Among different forest types, maximum soil carbon stock is found in dry deciduous forest followed by thorn forest and minimum in scrubland. The reason is soil carbon pool of forest differ according to climate, 


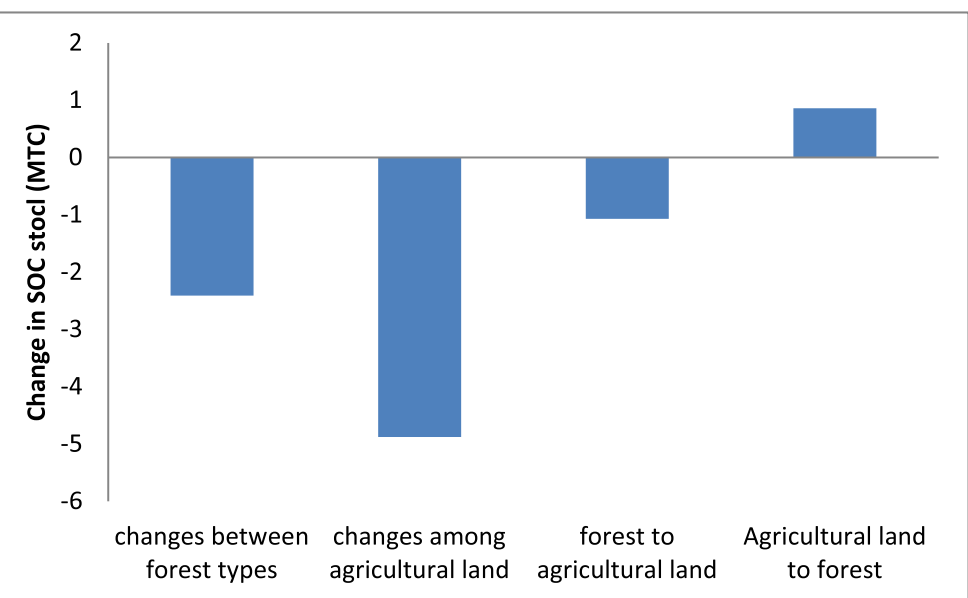

$\mathbf{a}$

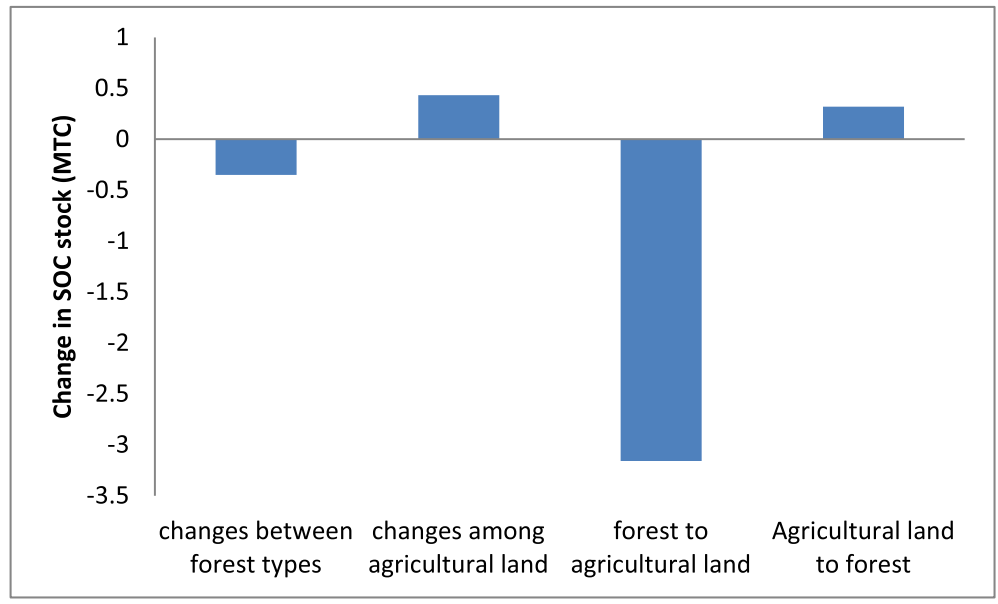

b

Fig. 8 Effect of major land use change on soil carbon stock (Mt C) in a 1993-2003 and b 2003-2014

location, age of the forest stand, and type of plant species (Noordwijk et al. 1997).

During 1993-2014, there is remarkable change in the SOC stock under agricultural lands. These results reflect the fact that the SOC pool in the cultivated lands is affected directly by the management practices adopted by the farmers. Interviews with farmers revealed that there was lower input of manure and fertilizer in cropland and plantation in 1993. After 1993, the farmers increased the input of fertilizer. During both the period, maximum loss in SOC was observed when dry deciduous forest was converted to other land types, i.e., cropland, scrubland, fallow land, and thorn forest. It is revealed that the change in forest land to other land causes oxidation of organic carbon in soil which leads to loss in SOC (Lal 2003; Lal 2004). The maximum rate of gain in SOC was observed when cropland was converted to dry deciduous forest.

\section{Conclusion}

To determine the dynamics of land use change, interpretation of multitemporal satellite imagery was found to be a practical method. The results showed that there was a continuous decrease in forest area, whereas area under agriculture increased steadily in each time period of 1993-2014. Matrices of land use change shows that in 1993-2003, highest internal trading occurred between forest types. In both the periods (1993-2003 and 20032014), maximum internal trading occurred among agricultural land followed by conversion of forest area to agricultural land.

This study also investigated the effect of land use change dynamics on SOC stock. Changes in the SOC pools were observed due to changes in land use or land management practices. In 1993-2003, changes among agricultural land leads to maximum loss of soil carbon and during 20032014 conversion of forest to agricultural land leads to 
maximum loss in soil carbon. There is gain in SOC stock in both the periods due to conversion of forest types to agricultural land. Overall, we can conclude that the internal trading of land use area during the 10-year period (19932003) leads to net loss of SOC stock by 8.29 Mt C. Similarly, land use change during the 11-year period (2003-2014) caused a net loss of SOC by $2.76 \mathrm{Mt} \mathrm{C}$.

This study concluded that land use change has a potential impact on soil carbon storage due to change or loss in vegetation which leads to alteration in input and output of carbon in soil. Efforts should be made to implement proper land use management practices, such as application of biofertlizers and organic manure to enhance the SOC content. Conversion of land use from cultivated to managed perennial plantation can enhance soil carbon stock. Land use management is an essential step for preserving existing soil carbon and also aids in increasing soil carbon. Semi-arid region has a great capacity to sequester carbon and this capacity can be enlarged if proper land use management is implemented. Also, these regions can contribute to mitigating carbon dioxide from the atmosphere.

\section{Abbreviations}

BD: Bulk density; ETM+: Enhanced thematic mapper plus; Fl: Stock change factor for organic matter input; FLU: Stock change factor for a specific land use pattern; FMG: Stock change factor for management practice; IPCC: Intergovernmental Panel on Climate Change; MTC: Metric ton carbon; OLI: Operational land imager; SOC: Soil organic carbon; SOCref: Default reference soil organic carbon; TM: Thematic mapper

\section{Acknowledgements}

Not applicable.

\section{Authors' contributions}

GS collected, interpreted, and analyzed the data and found the results and conclusion and was a major contributor in writing the manuscript. LK guided regarding spatial data analysis, KC guided regarding assessment of soil carbon stock. All authors read and approved the final manuscript

\section{Funding}

Non-JRF fellowship by Central University of Rajasthan.

\section{Availability of data and materials}

All data generated or analysed during this study are included in this published article [and its supplementary information files].

\section{Ethics approval and consent to participate}

Not applicable.

\section{Consent for publication}

Not applicable.

\section{Competing interests}

The authors declare that they have no competing interests.

\section{Author details}

'Department of Environmental Science, Central University of Rajasthan, NH-8, Bandarsindri, Rajasthan 305817, India. ${ }^{2}$ M.D.S. University, Ajmer, Rajasthan, India.
Received: 29 May 2019 Accepted: 9 September 2019

Published online: 05 November 2019

\section{References}

Allison LE (1975) Organic carbon. In: Black CA (ed) Methods of soil analysis. American Society of Agronomy 2, Madison, pp 1367-1378

Amin A, Singh SK (2012) Study of urban land use dynamics in Srinagar city using geospatial approach. Environ Sci Res 1(2):18-24

Amundson R (2001) The carbon budget in soils. Annu Rev Earth Planet Sci 29:535-562

Bajracharya RM, Sitaula BK, Shrestha BM, Awasthi KD, Balla MK, Singh BR (2004) Soil organic carbon status and dynamics in the central Nepal middle mountains. For J Inst For Nepal 12:2943

Bastawesy ME (2014) Hydrological scenarios of the renaissance dam in Ethiopia and its hydro-environmental impact on the Nile downstream. J Hydrol Eng 20:7

Batjes NH (1996) Total carbon and nitrogen in the soils of world. Eur J Soil Sci 47:151-163

Batjes NH, Sombroek WG (1997) Possibilities for carbon sequestration in tropical and subtropical soils. Glob Change Biol 3:161-173

Blake GR, Harte KH. 1986. Bulk density. In: A. Klute (ed) Methods of soil analysis part 1. Physical and mineralogical methods-Agronomy Monograph (2nd edn.), American Society of Agronomy-Soil Science Society of America, pp 363-375.

Chander G, Markham BL, Helder DL (2009) Summary of current radiometric calibration coefficients for Landsat MSS, TM, ETM+, and EO-1 ALI sensors. Remote Sens Environ 113(5):893-903

Davidson EA, Ackerman IL (1993) Changes in soil carbon inventories following cultivation of previously untilled soils. Biogeochemistry 20:161-193

Detwiler RP (1986) Land-use change and the global carbon cycle: the role of tropical soils. Biogeochemistry 2:67-93

Dewan AM, Yamaguchi Y (2009) Land use and land cover change in Greater Dhaka, Bangladesh: Using remote sensing to promote sustainable urbanization. Appl Geogr 29(3):390-401

Dhakal S, Koirala M, Sharma E, Subedi NR (2010) Effect of land use change on soil organic carbon stock in Balkhu Khola Watershed Southwestern part of Kathmandu Valley, Central Nepal. World Academy of Science. Eng Technol 66:581-591

Dimyati M, Mizuno K, Kitamura T (1996) An analysis of land use/cover change using the combination of MSS Landsat and land use map: a case study in Yogyakarta, Indonesia. Int J Remote Sens 17:931-944

Don A, Schumacher J, Freibauer A (2011) Impact of tropical land-use change on soil carbon stocks-a meta-analysis. Glob Change Biol 17:1658-1670

Eswaran H, van den Berge E, Reich P (1993) Organic carbon in soils of the world. Soil Sci Soc Am J 57:192-194

Friedlingstein P, Houghton RA, Marland G, Hackler J, Boden TA, Conway TJ, Canadell JG, Raupach MR, Ciais P, Le Quéré C (2010) Update on $\mathrm{CO}_{2}$ emissions. Nature Geoscience 3(12):811-812

Gammal EAE, Salem SM, Gammal AEA (2010) Change detection studies on the world's biggest artificial lake (Lake Nasser, Egypt). Egypt J Remote Sens Space Sci 13:89-99

Guo LB, Gifford RM (2002) Soil carbon stocks and land use change: a meta analysis. Glob Change Biol 8:345-360

Houghton RA (2003) Revised estimates of the annual net flux of carbon to the atmosphere from changes in land use and land management 1850-2000. Tellus 55:378-390

Houghton RA, Hackler JL (1999) Emissions of carbon from forestry and land-use change in tropical Asia. Glob Change Biol 5(4):481-492

Houghton RA, Hackler JL (2002) Carbon flux to the atmosphere from land-use changes. In: Trends: A Compendium of Data on Global Change. Carbon Dioxide Information Analysis Center, Oak Ridge National Laboratory, U.S. Department of Energy, Oak Ridge, Tenn, U.S.A.

IPCC (2000) Summary for Policymakers. Land use, land-use change, \& forestry: a special report of the intergovernmental panel on climate change.

IPCC (2003) Good practice guidance for land use, land-use change and forestry, national greenhouse gas inventories programme.

Kachhwala TS (1985) Temporal monitoring of forest land for change detection and forest cover mapping through satellite remote sensing. Paper presented at the 6th Asian Conference on Remote Sensing (NRSA, Hyderabad), pp 77-83

Lal R (2001) Soil degradation by erosion. Land Degrad Develop 12(6):519-539

Lal R (2003) Global potential of soil carbon sequestration to mitigate the greenhouse effect. Crit Rev Plant Sci 22(2):151-184 
Lal R (2004) Soil carbon sequestration to mitigate climate change. Geoderma 123(1-2):1-22

Lal R (2005) Forest soils and carbon sequestration. For Ecol Manag 220:242-258

Lambin EF, Ehrlich D (1997) Land-cover changes in Sub-Saharan Africa (19821991): Application of a change index based on remotely sensed surface temperature and vegetation indices at a continental scale. Remote Sens Environ 61(2):181-200

Leifeld J (2013) Soil carbon losses from land-use change and the global agricultural greenhouse gas budget. Sci Total Environ 46:3-6

Li X, Yeh AGO (2004) Analyzing spatial restructuring of land use patterns in a fast-growing region using remote sensing and GIS. Landsc Urban Plan 69(4):335-354

Luo Z, Wang E, Sun OJ (2010) Soil carbon change and its responses to agricultural practices in Australian agro-ecosystems: a review and synthesis. Geoderma 155:211-223

Mancinelli R, Campiglia E, Di Tizio A, Marinari S (2010) Soil carbon dioxide emission and carbon content as affected by conventional and organic cropping systems in Mediterranean environment. Appl Soil Ecol 46:64-72

Mehta A, Sinha VK, Ayachit G (2012) Land use/land cover study using remote sensing and GIS in an arid environment. Environ Sci Res 1(3-4):4-8

Mulders MA (2001) Advances in the application of remote sensing and GIS for surveying mountainous land. Int J Appl Earth Obs Geoinf 3(1):3-10

Murty D, Kirschbaum MK, McMurtrie RE, McGilvray H (2002) Does conversion of forest to agricultural land change soil carbon and nitrogen? a review of the literature. Glob Change Biol 8:105-123

Noordwijk VM, Cerri C, Woomer PL, Nugroho K, Bernoux M (1997) Soil carbon dynamics in the humid tropical forest zone. Geoderma 79(1-4):187-225

Ostle NJ, Levy PE, Evans CD, Smith P (2009) UK land use and soil carbon sequestration. Land Use Policy 26:274-283

Pooja K, Kumar M, Rawat JS (2012) Application of remote sensing and GIS in land use and land cover change detection: a case study of Gagas Watershed, Kumaun Lesser Himalaya, India. Quest 6(2):342-345

Post WM, Kwon KC (2000) Soil carbon sequestration and land-use change: processes and potential. Glob Change Boil 6:317-328

Powlson DS, Whitmore AP, Goulding KWT (2011) Soil carbon sequestration to mitigate climate change: a critical re-examination to identify the true and the false. Eur J Soil Sci 62(1):42-55.

Ram B, Kolarkar AS (1993) Remote sensing application in monitoring land-use changes in arid Rajasthan. Int J Remote Sens 14(17):3191-3220

Rembold F, Carnicelli S, Nori M, Ferrari A (2000) Use of aerial photographs, landsat TM imagery and multidisciplinary field survey for land-cover change analysis in the lakes region (Ethiopia). Int J App Earth Obs Geoinf 2(3-4):181-189

Sainju UM, Jabro JD, Stevens WB (2008) Soil carbon dioxide emission and carbon content as affected by irrigation tillage cropping systems, and nitrogen fertilization. J Environ Qual 37:98-106

Schreier H, Shah PB, Lavkulich LM, Brown S (1994) Maintaining soil fertility under increasing land use pressures in the middle mountains of Nepal. Soil Use Manag 10:137-142

Sharma L, Pandey PC, Nathawat MS (2012) Assessment of land consumption rate with urban dynamics change using geospatial techniques. J Land Use Sci 7(2):135-148

Shrestha BM, Sitaula BK, Singh BR, Bajracharya RM (2004) Fluxes of $\mathrm{CO}_{2}$ and $\mathrm{CH}_{4}$ in soil profiles of a mountainous watershed of Nepal as influenced by land use, temperature, moisture and substrate addition. Nutr Cycl Agroecosyst 68:155-164

Singh P, Gupta P, Singh M (2014) Hydrological inferences from watershed analysis for water resource management using remote sensing and GIS techniques. Egypt J Remote Sens Space Sci 17:111-121

Sombroek W, Nachtergaele F, Hebel A (1993) Amounts, dynamics and sequestering of carbon in tropical and subtropical soils. Ambio 22:417-426

Wairiu M, Lal R (2003) Soil organic carbon in relation to cultivation and topsoil removal on sloping lands of Kolombangara, Solomon Islands. Soil Tillage Res 70(1):19-27

Xia XQ, Yang ZF, Liao Y, Cui YJ, Li YS (2010) Temporal variation of soil carbon stock and its controlling factors over the last two decades on the southern Song-nen Plain, Heilongjiang Province. Geosci Front 1:125-132

Xia XQ, Yang ZF, Yu T, Hou QY, Bai RJ, Cui YJ (2011) Soil carbon source/sink caused by land use change in the last decades of the last century in Northeast China. Earth Sci Front 18:41-48
Yimer F, Ledin S, Abdelkadir A (2007) Change in soil organic carbon and total nitrogen contents in three adjacent land-use types in the Bale Mountains, southeastern highlands of Ethiopia. For Ecol Manag 242:337-342

Yuan F, Sawaya KE, Loeffelholz B, Bauer ME (2005) Land cover classification and change analysis of the Twin Cities (Minnesota) Metropolitan Area by multitemporal Landsat remote sensing. Remote Sens Environ 98:317-328

\section{Publisher's Note}

Springer Nature remains neutral with regard to jurisdictional claims in published maps and institutional affiliations.

\section{Submit your manuscript to a SpringerOpen ${ }^{\circ}$ journal and benefit from:}

- Convenient online submission

- Rigorous peer review

- Open access: articles freely available online

High visibility within the field

- Retaining the copyright to your article

Submit your next manuscript at $>$ springeropen.com 